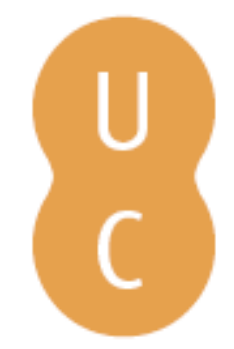

\title{
nommalina
}

\section{The natural origins of Greek art and culture, Greek landscape and the Greek brain}

\author{
Autor(es): Onians, John
}

Publicado por: Associação Portuguesa de Estudos Clássicos; Centro de Estudos

URL

persistente: URI:http://hdl.handle.net/10316.2/31530

DOI: $\quad$ DOI:http://dx.doi.org/10.14195/978-989-8281-69-2_1

Accessed : $\quad$ 26-Apr-2023 10:48:54

A navegação consulta e descarregamento dos títulos inseridos nas Bibliotecas Digitais UC Digitalis, UC Pombalina e UC Impactum, pressupõem a aceitação plena e sem reservas dos Termos e Condições de Uso destas Bibliotecas Digitais, disponíveis em https://digitalis.uc.pt/pt-pt/termos.

Conforme exposto nos referidos Termos e Condições de Uso, o descarregamento de títulos de acesso restrito requer uma licença válida de autorização devendo o utilizador aceder ao(s) documento(s) a partir de um endereço de IP da instituição detentora da supramencionada licença.

Ao utilizador é apenas permitido o descarregamento para uso pessoal, pelo que o emprego do(s) título(s) descarregado(s) para outro fim, designadamente comercial, carece de autorização do respetivo autor ou editor da obra.

Na medida em que todas as obras da UC Digitalis se encontram protegidas pelo Código do Direito de Autor e Direitos Conexos e demais legislação aplicável, toda a cópia, parcial ou total, deste documento, nos casos em que é legalmente admitida, deverá conter ou fazer-se acompanhar por este aviso.

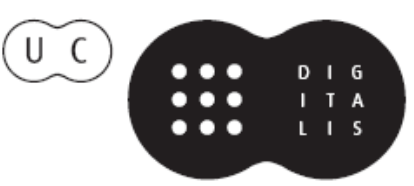




\section{Espaços e Paisagens}

Antiguidade Clássica

e Heranças Contemporâneas

Vol. III

Francisco Oliveira, Jorge Oliveira e Manuel Patrício

IMPRENSA DA UNIVERSIDADE DE COIMBRA 


\title{
THE NATURAL ORIGINS OF GREEK ART AND CULTURE. GREEK LANDSCAPE AND THE GREEK BRAIN
}

\author{
JOHN ONIANS \\ University of East Anglia
}

Keywords: Greek art, Greek brain, Greek culture, Greek landscape.

Palavras-chave: arte grega, cérebro grego, cultura grega, paisagem grega.

All Classicists know that the Greeks were distinguished for their interest in nature. They themselves are usually distinguished for their lack of interest in it; though that is not true of the organizers of this volume. Most Classicists study Greek natural philosophy and the naturalism of Greek art, but, in their explanation of them, they almost never themselves invoke nature. In this they are unlike their predecessors. In Antiquity the Hippocratic corpus and Strabo were in agreement that, following humoural theory, the main determinants of culture were climate and landscape. Thus the reason why the Athenians were more intelligent than the Boeotians was because their air was not moist and foggy, but dry and clear. In the eighteenth century, Winckelmann thought that Greek culture was fundamentally shaped by the climate and the influence it had on their brain, which he thought had finer fibres than those of the Egyptians and Persians. In the nineteenth, Hippolyte Taine agreed with ancient writers in claiming that the clarity of the Athenian air and the prismatic forms of their mountains played a crucial role in the emergence of the Athenian intellectual and aesthetic achievement. Such claims have tended to be treated as a joke by serious scholars, but now the joke is on them. Modern biology suggests that these neglected claims were essentially correct, although the basis for this opinion is not, of course, humoural theory, but neuroscience. In other words, while until recently anyone who argued that nature had an important role in shaping Greek culture would have been laughed at, we should now laugh at anyone who denies it. And surely, however skeptical we are, since the Greeks themselves were so interested in natural explanations we owe it to them to take such explanations seriously, which is why, in the next twenty five minutes, I intend to sketch out my own view of the way an understanding of the relation between two aspects of nature, the Greek brain and the Greek landscape, helps us to understand some of the most vital Greek achievements.

Since my argument may be unfamiliar to most of you I will first quickly outline its basis. I rely on two facts, one, the distinctive nature of the Greek landscape, and two, the distinctive nature of the Greek brain. For the Greek landscape was essentially different from that of all other areas of the world 
of a comparable state of development, a point which emerges starkly if one compares the Greek peninsula with the other three that project into the Mediterranean, Asia Minor, Italy and Spain. While all the others have closed and simple shapes, that of Greece is characterized by a bewildering variety of inlets and projections. These betray a unique geological history, which endowed the Greek peninsula with a unique topography, consisting of narrow fertile valleys divided from each other by steep mountains crowned by ridges of bare rock. This topography had a profound effect on the economic and social development of the peninsula, and it also had a profound effect on another natural phenomenon, the Greek brain. The point is not that the Greeks were born with special brains, but that the double influence of being exposed, both to such an environment itself, and to the economic and social practices that it nourished, caused their brains to develop in unprecedented ways. I don't have the time to fully lay out the neural basis of this claim, which I develop in my latest book, Neuroarthistory. From Aristotle and Pliny to Baxandall and Zeki, but the central point is the importance of neural plasticity. This is the principle that ensures that, although we are all born with a brain containing a hundred billion neurons, each of these neurons can have up to 100,000 connections to other neurons, and these connections are different in each of us, being formed and broken throughout our lives in response to all our individual experiences. This process is evident in the formation of connections in the infant cortex in the first two years of life. Its impact is most obvious when we consciously acquire a skill such as learning a language or playing a musical instrument, and its significance can be quantified if we observe the way repeating an activity, such as touching, over a few weeks causes a dramatic enlargement of the areas of the brain controlling the fingers involved. But what the historian of culture needs to know is that the same thing happens as we use all the other senses, for example as we look at the sky or the landscape and observe the movements of those around us. This is because the nerve cells in the visual system, such as the banks of neurons which respond to lines of different orientation, whose function in critical for our perception of form, respond better the more often they are activated. The principles governing the formation of our neural networks, mean that whatever the shapes of the natural and manmade objects we give attention to, and whatever the properties of the substances of which they are made, we will acquire a preference for looking at such shapes and a special empathy for those properties. Such unconscious and passive exposure is as important as that which is active and conscious. Indeed, since the unconscious process starts the moment we are born, and we only later develop conscious and active behaviours, the character of those later behaviours is profoundly influenced by our earlier experiences. And this of course is why it is so important to be aware of the consequence of such exposure in the context of this volume around the topic of landscape. There was no feature of the Greek environment, which was more striking and distinctive than landscape, and 
that alone is a reason for considering the role it might have had in shaping the Greek brain.

The influence of landscape on the brain is of two kinds. One is the direct influence of the landscape itself on neural networks, to which I will return at the end, but equally important is the influence of landscape on Greek life and social institutions, and here too we have to consider the consequences for the brain's passive exposure. Since the topography I have just described had a profound effect on the character of the Greek life-style and that lifestyle had a profound effect, both conscious and unconscious, on the Greek brain, we have to consider that effect as such. This effect is most clear in the way it affected the development of the urban institutions for which Greece is famous. The constraints inherent in the Greek landscape meant that the institutions that emerged in Greek towns were quite different from those found in towns in areas such as Egypt, Mesopotamia, and the Levant. In those areas the security of cities depended on the strength of rulers and the reliability of alliances. In Greece, the fractured landscape meant that security depended on very different factors. The villages that became towns as they grew in the separate valleys after $1000 \mathrm{BC}$ were all in rivalry with each other. They also had no wealthy protectors to look to. Instead, as the populations of each of these communities outgrew their local agricultural resources, each looked enviously at its rival's lands. Each city state needed an army, whether it was just to defend its own territory, or also to conquer that of its neighbour, and in the absence of protectors the only ways of increasing the army's effectiveness was to maximizing the strength of the only available body of fighting men, the limited numbers of the town's males. It was in response to these pressures that the Greek cities developed unique military tools. They thus concentrated on developing such attributes in the city's able bodied males as discipline, physical strength, rigorous co-ordination and equipped them with strong bronze body armour and iron weaponry. By doing so they enabled their warriors to form an impregnable regular formation, the phalanx. They also surrounded themselves with walls built out of squared blocks of limestone from the omnipresent mountains. So universal was the reliance on the phalanx and the stone wall that Homer already in the eighth century BC compares Achilles marshalling of his phalanx of Myrmidons, shield pressed against shield, their spears forming a fence, to a man building a wall out of tight fitting stones, and Greek soldiers were still being compared to stones in a wall by Plato in the fourth century.

The extent to which the unique techniques of warfare nurtured by the unique Greek landscape, deeply affected Greek culture is first apparent in the equally unique myths they had of their origin and nature. While all other peoples thought of themselves as being made of soft clay or descended from animals or plants, the Greeks were along in thinking of themselves as hard minerals. The Greek creation myth told how they were born when the only survivors after a great flood, Deucalion and Pyrrha, who were too old to have children, were told by the gods to throw stones over the shoulders. Those 
stones became the ancestors of the different Greek tribes. In a similar vein Hesiod in the Theogony talks of the succeeding populations of the gold, silver, bronze and iron ages and in the case of the bronze age at least, which was the one that preceded his own, told how the men themselves were made of bronze. The Greeks then, unlike all other peoples of the planet, liked to think of themselves as made of stone or metal, and, since those hard substances are the ones on which their landscape caused them to rely for defence there can be no doubt it was military priorities which inspired this chilling, but beneficial vision. There can be no doubt that an army of men who think of themselves as actually made of stone and metal would have had a critical psychological advantage when confronting one that thinks it is made of brittle clay, or descended from animals, as is confirmed by the Greek successes against their neighbourst to the East.

This empathetic relationship was critical for all aspects of culture, and this is nowhere more obvious than in art. For a start, the attributes of Greek so-called Geometric pottery, the rows of warriors with their regular shields and parallel spears, are a perfect illustration of the properties of the phalanx of Myrmidons as described in the Iliad. But even more striking is the unprecedented emergence of life-size and life-like statues in marble and bronze after 600BC. Since the Greeks had long been thinking of themselves as made of stone and metal it was entirely natural that they should represent themselves in those materials. In doing so they were not analytically trying to solve an artistic problem, as is often suggested, but doing no more than representing themselves for what they thought they were, made of hard stone and hard metal. The naturalistic style of the statues was also as much a product of the environment as the materials used, since all the sculptors were doing was representing those anatomical features, the deltoids, the biceps, the stomach muscles whose effectiveness had to be maximised in preparation for Greek warfare. Both material and style were thus indirectly a product of the Greek landscape.

The same distinctive military culture that produced Greek sculpture, also shaped Greek architecture. As we have seen, writers from Homer to Plato compared warriors to stones in a wall and this had implications for the Greek idea of the perfect man. Simonides for example around 500BC, later quoted enthusiastically by Plato, says that it is difficult to find the perfect man 'wrought four square', and since the only context in which being wrought four square was normal was the building of walls it sound as if he is thinking of the perfect man as a square block in just such a structure. This didn't just affect the way they thought about and represented themselves, as when they represented the most admired men as block-like herms, it also changed the way they thought about architecture. It gave them a preference for walls that were not like Egyptian walls, for example, smooth and seamless in their surface, but walls made up of individual stones visibly aligned in rows. Parallel to the analogy with rows of square blocks in a wall is the analogy with the rows of columns that are the most distinctive feature of the Greek temple. We often forget that nowhere in the world were the houses 16 
of deities surrounded by regular rows of stone columns, but, when we look for an explanation for this eccentric feature, one is ready to hand in the correspondence with the phalanx, a formation whose effectiveness depended on it members maintaining an absolutely rigid rectangular configuration, even when advancing at speed. The analogy is confirmed not just by the way the eight deep Parthenon corresponds with the Spartan phalanx, the best of all, which at the time was eight deep, but by the way Euripides makes Iphigeneia, at the beginning of Iphigeneia in Tauris, have a dream in which she sees the last column of her father's palace sprout golden hair from the capital and emit the voice of her brother, Orestes, because, as she says, the columns of a house are sons. The play was performed in the Theatre of Dionysus, just under the newly constructed Parthenon, and the audience would naturally have applied the experience to the columns of that temple, the most important in their lives. It was also just such an approach to columns that led the designer of the Erectheum around the same time to replace the columns in one porch by six statues of women, the fluting of their skirts carefully arranged to correspond with the flutes of the Ionic columns of the other two porches.

All this may sound a little difficult to argue convincingly unless we take into consideration the other natural element that we tend to disregard, the brain. The brain unconsciously supported the responses suggested above, because of both inherited and acquired neurally-driven inclinations. Our brain makes us all, as children, feel warm towards our parents and our parents' friends, and that means that it makes us feel warm towards phenomena that share attributes with our parents. In Greece that meant that infants would have been liable to feel warm towards lumps of stone. Ancient Greeks, like the modern descendants, would have had a light brown or bronzed colour, a colour that was like both weathered limestone and bronze, and Greek babies crawling and walking around their valley floor homes would have frequently encountered lumps of rock that had rolled down the mountains. These, because of their size and colour, would have had sufficient properties in common with their parents that they would have evoked similar feelings. Young Greeks would have felt that rocks were like people long before the social pressures also shaped by the landscape made them wish they had stone or metal ancestors. We can even confirm fotr them to really experienced such boulders as people, because Homer compares Hector's charge to the way a boulder rolls down a mountain and then stops. The combination of the Greek landscape and the Geek brain made them feel closer to stone than any other people on the planet before or since.

Many other aspects of Greek culture owe their origins if not directly to Greek landscape, at least to the military lifestyle it called forth. The first to consider is the interest in all aspects of mathematics and especially geometry. We have already seen how the requirement, enforced by the landscape, to maximise the efficiency of warriors in the military machine made the Greeks place an unprecedented emphasis on regularity, as in the phrases of Homer and the contemporary rows of warriors on Geometric vases. And it needs 
emphasising that the Greeks had no independent interest in geometry at this stage. What we call geometry is nothing more than the regularity required for effective warfare. The dependence of the need for order on military values is apparent throughout Greek history. Hesiod, for example, in an early acknowledgement of the role of music in Greek warfare describes how the function of the goddess Harmonia is to keep the ranks of the phalanx together. And the connection between music, mathematics and military values is explicit in Pythagoras. Pythagoras saw how Harmonia gave the universe the property of Kosmos that is battle order, such as that embodied in the phalanx, and his closest followers were the first mathematikoi at Croton, a city he sought out because its young men were the healthiest in the Greek world and whose population he is supposed to have incited to attack the neighbouring city of Sybaris, in order to demonstrate the superiority of warriors in whom mathematical knowledge was primary. Pythagoras defined the main elements of a mathematical training as arithmetic, geometry, music and astronomy and Plato adopted them as the core of the education of the phylakes, the guardians of his Republic, explaining each in military terms. Arithmetic was necessary to count the soldiers, geometry to organize them into formations, music to give them order and astronomy to determine the right season to fight. We have come to think that the Greek interest in mathematics was purely intellectual and abstract, and it certainly became that after they were conquered by the Romans, but in Greece it was rooted in the type of warfare nourished by the Greek landscape.

The same is true of the idea of education itself. It is well understood that the Greeks took the mental training of young men much further than any of their contemporaries, but it is not often realised why. It was only because it was the best way of maximising their efficiency in warfare. No one puts all that effort into the formation of the young unless it has a clear social benefit, and in Greece the benefit was military. Indeed the military roots of Greek education, and its specifically mathematical focus, are well illustrated by the sentence of Simonides quoted earlier in which it said it was difficult to find the perfect man, that is one made four square. As we said then, the reason why foursquare men were needed was because warriors had to be like square blocks in a wall. The more foursquare they were the better they would fit together. It was also significant that Simonides referred to men being 'wrought' four square, that is shaped, as by the chisel of a mason, which makes clear that the reference is to a man who is stone-like, and that reminds us that one of the great benefits of the Greeks thinking of themselves as stone-like was that it meant that they could be endlessly shaped and reshaped. The difference from the thinking of other peoples could not be clearer. Almost all other peoples thought of themselves as made of clay, as did the Chinese, a material which after its first moulding has a shape that is fixed until it is broken, at which time it becomes useless. When the Greeks thought of themselves as made of stone - or for that matter of metal - they thought of themselves as made of a material that could be endlessly reworked, that is was endlessly susceptible 
to reformation, the body by training and the mind by education. Since the Middle Eastern peoples who developed the idea that they were made of clay did so because they were brought up in valleys where the best things, the plants on which their prosperity depended, grew out of mud, and the Greek idea of themselves as made of stone and metal was born from exposure to a mountainous environment, in which the best things were the metal weapons and stone walls with which they defended themselves, the Greek self-image, was, like all other aspects of their culture, a product of the Greek landscape, and since thinking of themselves as mineral was crucial to the sense that they were endlessly reshapable it is clear that landscape was also crucial for the development of Greek ideas of education.

Reference to the importance of the linear clarity of geometry in Greek education brings me to my final point in this study of the relation between Greek culture and Greek landscape. We have seen that in antiquity the clarity of Athenian thought when compared to that of neighbouring Boeotia was associated with the limpid clarity of the Athenian air, and a hundred and fifty years ago Hippolyte Taine made a similar claim in relation to Athenian aesthetics: "...it is the physical structure of the land that has left on the intelligence of the race the imprint that we find in its works and in its history...The eye grasps effortlessly the shapes of objects and takes from them a clear image"". The fact that everywhere are bare rocky mountains only strengthens the effect, which is especially characteristic of Attica where the air is particularly clear: "It is thus that nature, by the forms with which it populates his spirit, inclines immediately the Greek to firm and clear conceptions". Taine was encouraged to make his bold assertion, which has often been ridiculed, by recent discoveries showing that the nervous system is made up of a myriad nerve cells connected to each other by tiny filaments here illustrated by the Spanish neuroscientist Ramon y Cajal, and now we can use the latest neuroscience to argue that he was probably right. The primary cells involved in form perception are, as we saw earlier, banks of neurons each of which respond to lines of a different orientation, and the more such cells are activated by exposure to such lines the more the connections between them develop, so enhancing the preference for such lines. There was much in the Greek environment that was more linear than in that of Mesopotamia and Egypt, especially the metal weapons they used to fight and the tools with which they worked the stones of their buildings, but even more omnipresent were the rocks of the surrounding mountains, often, after millions of years of that unusual geological history that had produced the land's extraordinary fractured silhouette, hard and sharp in outline and riven by a multitude of fissures. In no place was this more true than at Athens, where bare mountains ringed the city, and where the prismatic acropolis stood at its centre. Exposure to such an environment rich in lines, would have had a distinctive impact on the neural networks of Greek infants, giving them a sensitivity to line greater than that found in other populations elsewhere, and that effect would have been strengthened by exposure to the weapons and tools which 
were as essential to their lives as plants and animals were to others, giving them a preference for such properties as linearity and angularity. Indeed, exposure to these two elements of their environment, the natural and the manmade would have had a progressively incremental effect. Especially in the period after $650 \mathrm{BC}$, as they made more and more man-made objects out of the natural materials around them, incising black figure pottery with thin lines, and carving columns and entablatures with ever sharper mouldings and flutes, and giving their sculptures ever more graceful linear outlines, the distinctiveness of their neural networks and of the preferences they endowed them with would have become ever stronger. This would have been most true in Athens, where marble allowed linear properties maximal expression in the architecture and sculpture of the temple of Athena Nike, the Parthenon, the Erechtheum. And of course we should not forget that such exposure would also have allowed them to distinguish forms ever more clearly, building up unconsciously a clearer knowledge of the world than any available elsewhere.

Some of you may be reluctant to follow this argument, being doubtful if landscape can have such an effect on aesthetic sensibilities in other areas, so, in a last effort to persuade you, I will suggest that landscape also helps us to understand why the typical building of the Greeks, a pedimented temple, such as the Parthenon, is so different from the new types of building developed by the Romans, of which the Pantheon is the supreme example. It happens that Athens is surrounded by mountains, such as Mt Hymettus, chiseled by weather and geological pressures into rectangular massifs with long ridges along the top, while Rome is the only city in the world surrounded by tens of circular extinct volcanoes, their centres filled with round lakes, making them look as much like the Pantheon with its oculus as the mountains around Athens were like the Parthenon. Might exposure to those very different landscapes have had at least some influence on their neural networks, and so affected their tastes in architecture? If so it would be yet another example of how, far from being the product of conscious intellectual effort, as we have always been told, many, if not most, of the distinctive aspects of Greek culture are primarily the natural result of a purely passive exposure, either to landscape or to the social institutions that landscape inspired. 